\title{
INTRODUCTION AND ESTABLISHMENT OF TROPICAL ORNAMENTAL FISH, PTERYGOPLICHTHYS SPP. (ACTINOPTERYGII: SILURIFORMES: LORICARIIDAE) IN HOT SPRINGS: AQUARIUM TRADE AS A POTENTIAL RISK FOR BIODIVERSITY IN TURKEY
}

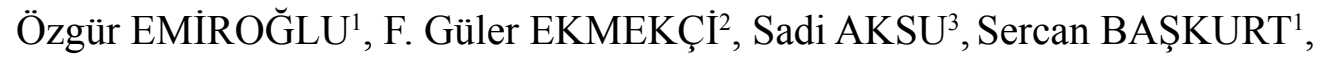 \\ M. Altuğ ATALAY ${ }^{4}$, and A. Serhan TARKAN ${ }^{5 *}$ \\ ${ }^{1}$ Faculty of Science, Department of Biology, Eskişehir Osmangazi University, Eskişehir, Turkey \\ ${ }^{2}$ Department of Biology, Hacettepe University, Faculty of Science, Ankara, Turkey \\ ${ }^{3}$ Vocational School of Health Services, Eskişehir Osmangazi University, Eskişehir, Turkey \\ ${ }^{4}$ General Directorate of Aquaculture and Fisheries, Ministry of Food, Agriculture and Livestock, Ankara, Turkey \\ ${ }^{5}$ Faculty of Fisheries, Muğla Sitkı Koçman University, Muğla, Turkey
}

Emiroğlu Ö., Ekmekçi F.G., Aksu S., Başkurt S., Atalay A., Tarkan A.S. 2016. Introduction and establishment of tropical ornamental fish, Pterygoplichthys spp. (Actinopterygii: Siluriformes: Loricariidae) in hot springs: Aquarium trade as a potential risk for biodiversity in Turkey. Acta Ichthyol. Piscat. 46 (4): $351-356$.

\begin{abstract}
The aim of this study was to report non-native tropical ornamental freshwater fish species from the Pınarbaşı Stream connected with hot-water sources in the İnönü Province (Eskişehir, Turkey). The morphological characters and meristic counts indicated that the examined specimens were: Pterygoplichthys disjunctivus (Weber, 1991), Pterygoplichthys pardalis (Castelnau, 1855), and their hybrids. We also present the evidence of their reproduction and establishment. Successful invasion of these species was evident, as their young-of-the-year and juvenile individuals were caught during the samplings from the same water course. Finally, we discuss the management implications of these species.
\end{abstract}

Keywords: aquarium species, hybrid, reproduction, invasion, management measures

The ornamental aquarium trade, along with the stocking for angling and aquaculture, is one of most important pathways of freshwater fish introduction (Gozlan 2008). Its importance, however, has been underestimated and only recently it was recognized as an important vector of aquatic invasive species (Padilla and Williams 2004, Duggan et al. 2006, Copp et al. 2007, Strecker et al. 2011). In a global perspective, the aquarium-traced introductions were reported to account for $21 \%$ of all freshwater fish introductions of more than 150 mainly freshwater fishes species (Fuller 2003, Gozlan 2008). Some continents, such as North America, where hundreds of aquarium species were reported to be in circulation, have been studied more extensively (Rixon et al. 2005, Duggan et al. 2006). A good example of less studied regions is the European continent with the exception of the UK (Copp et al. 2007, 2010). Andrews (1990) reported that around 208-589 million freshwater fish specimens were imported to the UK between 1987 and 1989. Recently, Maceda-Veiga et al. (2013) screened aquarium species composition in south-western Europe (mainly in Portugal and Spain) and found out 1133 fish species are on sale.

Several ornamental species, such as pond loach, Misgurnus anguillicaudatus (Cantor, 1842), have already been established in the European countries of the Mediterranean climate zone. Only three ornamental fishes have been reported in Turkish inland waters; goldfish, Carassius auratus (Linnaeus, 1758); red piranha, Pygocentrus nattereri Kner, 1858; and vermiculated sailfin catfish, Pterygoplichthys disjunctivus (Weber, 1991) with only goldfish being established (Tarkan et al. 2015). We would like to emphasize that eco-regions with hot water springs are especially susceptible for unwanted introductions (Emiroğlu 2011).

Species of Pterygoplichthys, commonly known as sailfin catfishes, are native to the South America. They are very popular aquarium fishes that have been introduced into several countries on different continents

* Correspondence: Prof. Dr. Ali Serhan Tarkan, Muğla Sttkı Koçman Üniversitesi, Su Ürünleri Fakültesi, 48000, Kötekli, Muğla, Turkey, phone: (+90) 2522111888, fax: (+90) 2522111887, e-mail: (AST) serhantarkan@gmail.com, (ÖE) hidrobiyolog75@gmail.com, (FGE) fgekmekci@gmail.com, (SA) sadiaksu@gmail.com, (SB) sercanbaskurt@gmail.com, (MAA)aatalay72@gmail.com. 
such as the USA, the Philippines, Taiwan, and Turkeymainly because of their high tolerance to environmental variations and feeding behaviour, which is very effective to clean algae from submerged surfaces (Hoover et al. 2004, Chavez et al. 2006, Yalçın Özdilek 2007, Wu et al. 2011, Nico et al. 2012).

Herbivorous sailfin catfishes are usually successful invaders across its invasive range (Zworykin and Budaev 2013) and several factors facilitate their invasion into a variety of ecosystems. The most import are: their water pollution tolerance, low oxygen level tolerance (aided by accessory respiration), predation defence tools, such as spiny fins and hard external armour (Zworykin and Budaev 2013), advanced spawning behaviour (batch spawning, extended spawning period, and parental care) (Hoover et al. 2004, Liang et al. 2005). The above-mentioned advanced surviving features of sailfin catfishes may have negative impact on the ecosystem and the biodiversity (Hoover et al. 2004, Zworykin and Budaev 2013). Their grazing behaviour may alter the food web, especially when they become abundant (Smith 1981). They eat demersal eggs of autochthonic species and out-compete other herbivore species (Hoover et al. 2004). Also, piscivorous birds were reported to be affected by strong spines of these fishes (Bunkley-Williams et al. 1994, Hoover et al. 2004). Their burrowing behaviour in the river banks may cause some socioeconomic problems such as the water turbidity and soil erosion. Moreover, sailfin catfishes also damage gillnets (Hubilla et al. 2007). Mendoza et al. (2015) using risk screening tool for freshwater fishes (Freshwater Invasiveness Screening Kit-FISK; Copp et al. 2009) determined a high invasiveness potential for Pterygoplichthys species in Mexico. The same has been estimated for several European countries (Simonović et al. 2013, Perdikaris et al. 2016) and Turkey (Tarkan et al. 2014). In those studies, high risk of invasiveness of this fish was associated with its advanced reproductive features, previous history of successful introductions, detrimental impacts to the recipient ecosystems, and its environmental versatility.

In Turkey, only a single specimen of Pterygoplichthys disjunctivus was reported from the Asi River (southern Turkey) (Yalçın-Özdilek 2007). The above-mentioned author noted that this single specimen indicated potentially serious ecological problems, if the species is established, especially for rich endemic fish fauna of the river. However, following-up surveys found no other $P$. disjunctivus specimens in the river. Although the exact date is unknown, the most plausible way for Pterygoplichthys species to enter the Asi River and the hot water resources in İnönü town is the result of aquarium release or escape. Indeed, one wholesaler admitted that he released many aquarium fishes into spring waters around İnönü town (Sakarya River Basin, north-western of Turkey) some 7-8 years ago when he went bankrupt. Our surveys have confirmed that aquarists still damp these species and personal communications revealed that ornamental poeciliids and cichlids are purposefully being released to hot springs, because their natural water parameters are believed to be suitable for the species' survival. In addition to the introduced Pterygoplichthys spp., there are three endemic species co-habiting waters in İnönü town: Caucasian bleak, Alburnus escherichii Steindachner, 1897; Sakarya chub, Squalius pursakensis (Hankó, 1925); and Aphanius villwocki Hrbek et Wildekamp, 2003.

Material and methods. Fish samples were collected from the Pınarbaşı Stream (near the town of İnönü) fed by hot spring waters. This stream originates from a rocky region in western part of the basin and joins the Porsuk River, a major tributary of the Sakarya River $\left(39^{\circ} 48^{\prime} 48.60^{\prime \prime} \mathrm{N}, \quad 30^{\circ} 07^{\prime} 04.05^{\prime \prime} \mathrm{E}-39^{\circ} 49^{\prime} 00.08^{\prime \prime} \mathrm{N}\right.$ $\left.30^{\circ} 07^{\prime} 53.90^{\prime \prime} \mathrm{E}\right)$. At the sampling site, the stream is approximately $250 \mathrm{~cm}$ wide, the current is slow, and the temperature is $22-26^{\circ} \mathrm{C}$ throughout the year. The mean $\mathrm{pH}$ and mean electrical conductivity are 6.69 and $442 \mu \mathrm{S}$. $\mathrm{cm}^{-1}$, respectively. The water depth is between 30 and 150 $\mathrm{cm}$ with a muddy and plant-covered substrate. There are several artificial channels and weirs along the water course. Pterygoplichthys spp. occur in $1290 \mathrm{~m}$ long section of the stream, being most abundantly along the natural part (590 $\mathrm{m})$. The stream is mainly covered by mud and submerged aquatic vegetation (Fig. 1).

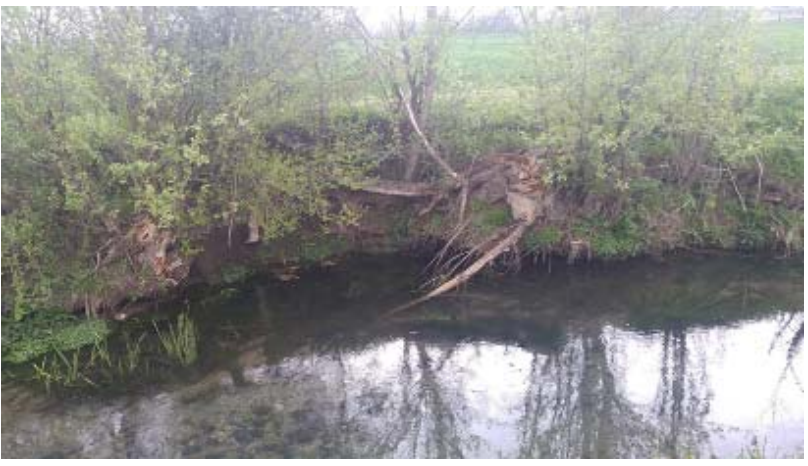

Fig. 1. A section of the Pınarbaş1 Stream where Pterygoplichthys species were most abundantly caught

Fish samples were collected on 09 March 2016 and 15 March 2016 with an electrofishing device (Samus 725-PWM2). Collected fishes were euthanized using an overdose of 2-phenoxyethanol and transported on ice to the laboratory where they were examined for morphometric characters.

The standard length and total length of the specimens were measured to the nearest $\mathrm{mm}$ and weighted to the nearest $0.01 \mathrm{~g}$. The fish were macroscopically examined and photographed. Some meristic characters such as the number of branched fin rays of dorsal, pectoral, and ventral fins were counted. The specimens were identified using taxonomic keys of Weber $(1991,1992)$ and Armbruster and Page (2006). All the counts and measurements were done according to Weber (1992), which largely follows Boeseman (1968) except the following ratios: head width $\div$ distance between posterior eye margins, head depth $\div$ head depth through eye. Other morphological characters were identified according to the description of Armbruster and Page (2006). A recent key on the web page of 
Armbruster* was used to verify the measurements. Species of the genus Pterygoplichthys can be easily distinguished from other loricariids by the following characters: presence of a short adipose fin, dorsally and laterally plated body, more than 10 teeth per jaw ramus, eight or more branched dorsal fin rays.

Results. The number of Pterygoplichthys individuals observed was about 400 in approximately $300 \mathrm{~m}$ stretch of the stream. This was the most abundant section of the area studied, in terms of the presence of those fish. This suggests high abundance of the species in this water course. The following characters indicated that examined species were the members of genus Pterygoplichthys: supraoccipital flat or rounded, not forming a median crest, a single buccal papilla, short odontodes on lateral plates, without hypertrophic odontodes on check plates, abdomen with dark spots on light background, dark spots often coalescing to form vermiculations.). The morphometric and meristic characters of the fish studied are presented in Table 1.

The performed morphological analysis (Table 1) given below showed that our specimens belong to Pterygoplichthys pardalis (Castelnau, 1855), Pterygoplichthys disjunctivus, and their hybrids. The main distinguishing characters between $P$. pardalis and $P$. disjunctivus are the design and pigmentation pattern of abdomen. Pterygoplichthys disjunctivus differs from
P. pardalis by having dark spots on the abdomen coalesced to form vermiculate pattern, whereas $P$. pardalis abdomen is covered with discrete spots. The specimens having a design pattern other than these two pattern were considered hybrids (Fig. 2). Notably, we found a wide inter-species variation in the design pattern. The meristic characters were also important to verify the genus, the branched fin rays of 22 specimens were counted, the number of dorsal fin rays were from 11 (number of individuals, $n=4$ ) to $13(n=1)$, mostly $12(n=18)$, whereas for pectoral rays varied between $5(n=8)$ and $7(n=1)$, mostly $6(n=14)$ and ventral rays between $4(n=11)$ and $5(n=12)$.

The majority of the characters of hybrids seemed to be closer to $P$. disjunctivus than $P$. pardalis. Many meristic characters such as head length, maximum body depth, and caudal peduncle height have smaller mean values in hybrids. Hybrids apparently differed from the P. pardalis and $P$. disjunctivus by having smaller eye diameter, smaller head depth, narrower caudal peduncle, shorter head, and lower maximum body depth.

Among the 22 fish individuals used for determining meristic characters, 9 (41\%) were congruently identified by the authors as Pterygoplichthys pardalis, 5 (23\%) presented external traits of Pterygoplichthys disjunctivus, and $8(36 \%)$ were assigned to the intermediate form. The standard, total length, and weight of all examined

Table 1

Morphometric and meristic counts of Pterygoplichthyes pardalis, Pterygoplichthyes disjunctivus and hybrid specimens from Pınarbaşı Stream, Turkey

\begin{tabular}{|c|c|c|c|c|c|c|}
\hline & \multicolumn{2}{|c|}{ P. disjunctivus $(n=5)$} & \multicolumn{2}{|c|}{ P. pardalis $(n=9)$} & \multicolumn{2}{|c|}{ Hybrids $(n=8)$} \\
\hline & Range & Mean \pm SD & Range & Mean \pm SD & Range & Mean \pm SD \\
\hline $\mathrm{SL}[\mathrm{mm}]$ & $190.00-296.54$ & $269.81 \pm 40.43$ & $109-283$ & $191 \pm 50.55$ & $135-351$ & $250 \pm 68.31$ \\
\hline $\mathrm{TL}[\mathrm{mm}]$ & $251.00-366.00$ & $334.25 \pm 48.26$ & $158.00-355.00$ & $254.00 \pm 57.66$ & $190-433$ & $325 \pm 71$ \\
\hline $\mathrm{HL}[\mathrm{mm}]$ & $42.13-73.22$ & $63.98 \pm 11.21$ & $25.40-53.06$ & $39.54 \pm 7.90$ & $29.43-71.72$ & $53.58 \pm 12.31$ \\
\hline \multicolumn{7}{|l|}{$[\% \mathrm{SL}]$} \\
\hline Head length & $22.17-25.42$ & $23.62 \pm 1.45$ & $18.30-23.30$ & $21.02 \pm 1.61$ & $20.16-23.16$ & $21.45 \pm 1.17$ \\
\hline Max body depth & $16.91-21.08$ & $18.78 \pm 1.56$ & $14.36-22.93$ & $18.09 \pm 2.89$ & $15.27-18.94$ & $16.86 \pm 1.16$ \\
\hline Predorsal distance & $38.27-40.80$ & $39.75 \pm 1.08$ & $36.77-42.58$ & $39.78 \pm 1.76$ & $36.09-40.85$ & $38.66 \pm 1.59$ \\
\hline Prepelvic distance & $45.78-49.13$ & $46.67 \pm 1.40$ & $42.93-47.73$ & $45.44 \pm 1.53$ & $43.53-46.63$ & $45.19 \pm 1.18$ \\
\hline Preanal distance & $66.02-73.19$ & $68.87 \pm 2.80$ & $64.61-70.92$ & $68.81 \pm 1.97$ & $64.95-69.09$ & $66.72 \pm 1.21$ \\
\hline Pectoral-anal distance & $46.47-49.50$ & $48.23 \pm 1.33$ & $43.38-50.90$ & $46.82 \pm 2.82$ & $42.65-53.05$ & $46.28 \pm 3.62$ \\
\hline Pectoral-pelvic distance & $19.96-25.57$ & $23.19 \pm 2.10$ & $21.59-24.81$ & $23.23 \pm 1.00$ & $20.59-27.11$ & $23.13 \pm 2.02$ \\
\hline Pelvic-anal distance & $22.92-26.61$ & $25.29 \pm 1.44$ & $20.56-25.25$ & $23.21 \pm 1.73$ & $21.8-25.53$ & $23.69 \pm 1.34$ \\
\hline Length of dorsal spine & $23.31-27.77$ & $25.55 \pm 1.85$ & $23.26-27.22$ & $25.46 \pm 1.54$ & $21.18-25.93$ & $23.99 \pm 1.54$ \\
\hline Length of anal fin & $14.14-18.48$ & $16.38 \pm 1.81$ & $13.72-17.72$ & $15.64 \pm 1.24$ & $13.32-15.38$ & $14.72 \pm 0.91$ \\
\hline Length of pectoral fin & $29.19-3.77$ & $31.60 \pm 2.02$ & $29.57-34.25$ & $32.04 \pm 1.65$ & $28.38-32.86$ & $30.60 \pm 1.6$ \\
\hline Length of pelvic fin & $19.78-23.79$ & $21.84 \pm 1.58$ & $20.52-25.54$ & $23.03 \pm 1.67$ & $17.20-23.36$ & $20.43 \pm 2.33$ \\
\hline Caudal peduncle height & $8.73-9.84$ & $9.33 \pm 0.43$ & $7.59-10.64$ & $8.76 \pm 0.96$ & $5.12-8.09$ & $6.84 \pm 1.35$ \\
\hline \multicolumn{7}{|l|}{$\% \mathrm{HL}$} \\
\hline Snout length & $52.24-72.85$ & $61.00 \pm 7.70$ & $52.24-72.85$ & $61.00 \pm 7.70$ & $49.93-77.87$ & $61.34 \pm 11.81$ \\
\hline Eye diameter & $19.32-26.61$ & $22.31 \pm 2.62$ & $19.32-26.61$ & $22.31 \pm 2.62$ & $16.12-28.07$ & $19.42 \pm 3.83$ \\
\hline Interorbital distance & $57.55-70.93$ & $62.26 \pm 4.08$ & $57.55-70.93$ & $62.26 \pm 4.08$ & $56.45-65.42$ & $60.94 \pm 3.33$ \\
\hline Head width (at eyes) & $100.19-120.93$ & $107.16 \pm 6.44$ & $100.19-120.93$ & $107.16 \pm 6.44$ & $92.23-111.99$ & $102.02 \pm 6.54$ \\
\hline Head depth (at eyes) & $60.24-79.16$ & $69.04 \pm 6.12$ & $60.24-79.16$ & $69.04 \pm 6.12$ & $53.99-69.38$ & $62.75 \pm 5.65$ \\
\hline
\end{tabular}

$\mathrm{SL}=$ standard length, $\mathrm{TL}=$ total length, $\mathrm{HL}=$ head length; $\mathrm{SD}=$ standard deviation. 
specimens amounted to $10.9-35.1 \mathrm{~mm}, 15.8-43.3 \mathrm{~mm}$, and 24.0-647.5 g, respectively. We dissected 9 specimens and found that all the dissected specimens were females, among those specimens 5 had ripening eggs in ovaries, others with ovaries in developing or resting stage. One of the ovaries was significantly smaller than the other (Fig. 3).

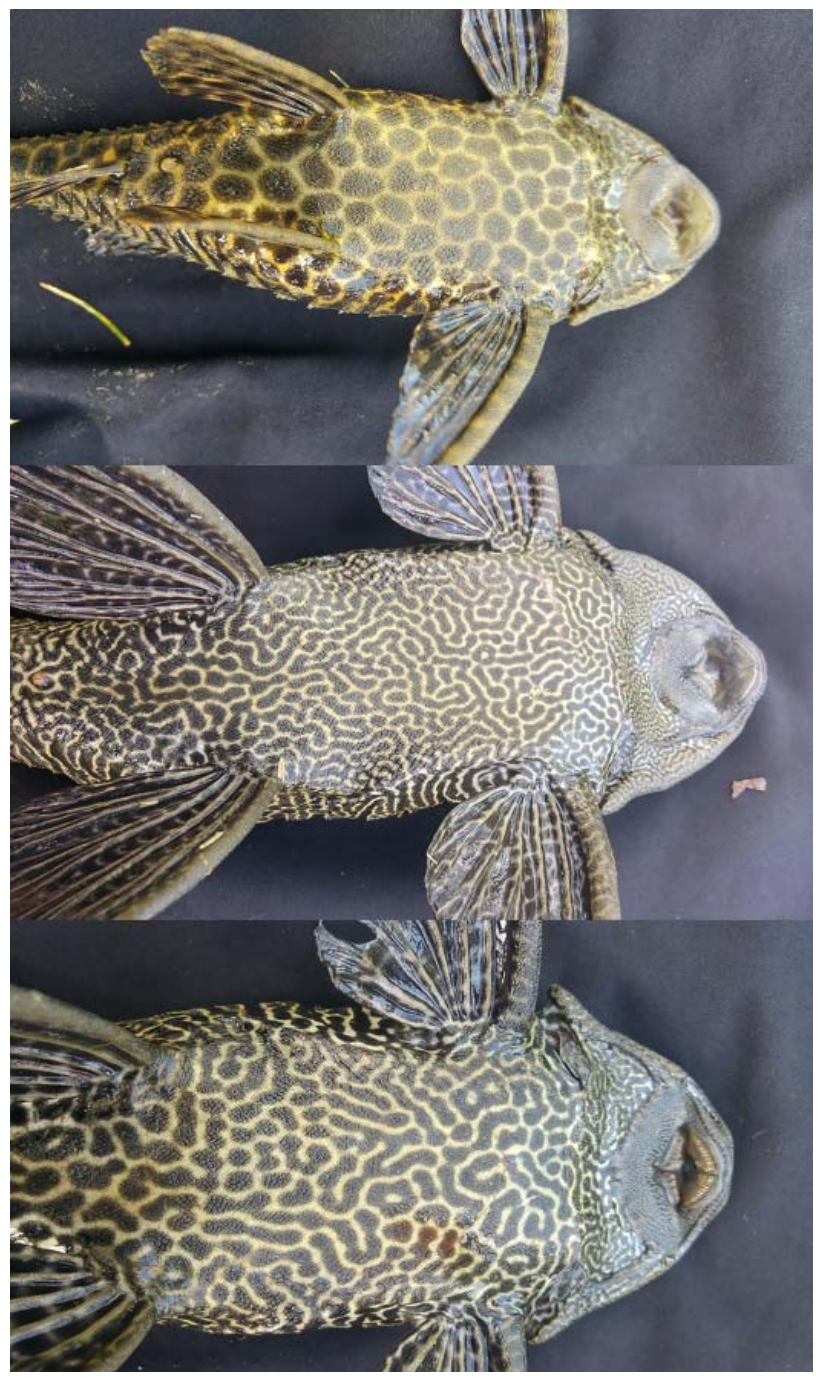

Fig. 2. Ventral views of Pterygoplichthyes pardalis (upper), Pterygoplichthyes disjunctivus (middle), and a hybrid of these species (bottom)

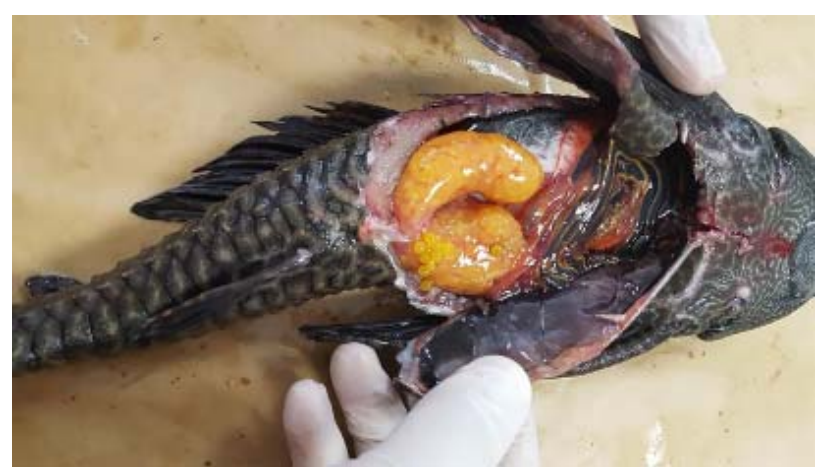

Fig. 3. A Pterygoplichthys individual with ripening eggs
Pterygoplichthys species were observed to prefer consistently dense vegetation on the bottom of the water course and avoid rocky microhabitats. Young-of-the-year and juvenile individuals of fish species under study were caught during the samplings from the stream, indicating their successful invasion. Further, we found that the crevices along the lateral walls of the water course were used by Pterygoplichthys spp. for laying their eggs.

Remarks. Our morphological analyses on the collected specimens from the stream (in İnönü town) fed hot spring water indicated that non-native Pterygoplichthys species should be identified as $P$. disjunctivus and $P$. pardalis or their hybrids. Indeed, identification of Pterygoplichthys species is highly complicated because of intra-specific variation and likely natural and artificial hybridization (Hoover et al. 2004, Wu et al. 2011, Nico et al. 2012). Previous genetic-based identification studies explain this difficulty and usually found almost no genetic difference between these species (Wu et al. 2011, Bijukumar et al. 2015). The identification of the specimens in the presently reported study followed Weber (1991, 1992), Armbruster and Page (2006), Chavez et al. (2006), and Wu et al. (2011). All showed that the main distinguishing character between $P$. disjunctivus and $P$. pardalis is that the former has reticulate dark pattern on the ventral surface while the later has a spotted pattern. It is worth noting that our specimens have abdomen design pattern that closely resembles that of $P$. disjunctivus as shown by $\mathrm{Wu}$ et al. (2011). However, Armbruster and Page (2006) noted that adult $P$. disjunctivus do not have geometric patterns on the head while our specimen does, suggesting that it is a hybrid or a specific variation. This can be confirmed more clearly by the key in the website on the Loricariidae by Jonathan Armbruster*.

Given that Pterygoplichthys species have been widely reported to severely impact native biota, our findings on the first abundant and reproducing established populations of these species in Turkey should have very important management implications. In particular, hybrid specimens found in relatively higher numbers should be carefully monitored, as previous reports clearly indicated that the superiority of the hybrid might have helped increase its fitness during population invasions (Wu et al. 2011). It is obvious that the springs and spring runs where Pterygoplichthys species have been caught in the presently reported study serve as thermal refuges in winter for these tropical fishes however their high abundances and wide distribution may lead to displace the native fish and endemic species that are found in the same water course and disturb ecosystem structure and services.

Bio-ecological features, reproductive traits, environmental tolerances and possible ecosystem impacts of Pterygoplichthys species should continuously be monitored in these spring water sources to determine risk levels and management actions of the species. Thermal refuge condition of the region and strong habitat preferences of the species (i.e., abundant vegetative microhabitats) may also 
provide an opportunity to properly eradicate these species, which warrants further studies. It should be noted that deciding an eradication or control program requires the information on vulnerability of the habitats, propagule pressure, interconnectivity with source population and available funds along with the knowledge of impacts and biology of the non-native species (Hill and Sowards 2015).

\section{ACKNOWLEDGEMENTS}

This study was supported by a public health and environmental consulting firm so called "eco-zone" with a project on biodiversity inventory and monitoring terrestrial and inland systems of Eskişehir Province.

\section{REFERENCES}

Andrews C. 1990. The ornamental fish trade and fish conservation. Journal of Fish Biology 37 (Suppl. A): 53-59.

DOI: 10.1111/j.1095-8649.1990.tb05020.x

Armbruster J.W., Page L.M. 2006. Redescription of Pterygoplichthys punctatus and description of a new species of Pterygoplichthys (Siluriformes: Loricariidae). Neotropical Ichthyology 4 (4): 401-409.

Bijukumar A., Smrithy R. Sureshkumar U., George S. 2015. Invasion of South American suckermouth armoured catfishes Pterygoplichthys spp. (Loricariidae) in Kerala, India - a case study. Journal of Threatened Taxa 7 (3): 6987-6995.

DOI: $10.11609 /$ JoTT.o4133.6987-95

Boeseman M. 1968. The genus Hypostomus Lacépède, 1803, and its Surinam representatives (Siluriformes, Loricariidae). Zoologische Verhandelingen (Leiden) 99: $1-89$.

Bunkley-Williams L., Williams E.H., Lilystrom C.G., Corujo-Flores I., Zerbi A.J., Aliaume C., Churchill T.N. 1994. The South American armored catfish, Liposarcus multiradiatus (Hancock), a new exotic established in Puerto Rican fresh waters. Caribbean Journal of Science 30 (1-2): 90-94.

Chavez J.M., Paz R.M.D., Manohar S.K., Pagulayan R.C., Carandang J. 2006. New Philippine record of South American sailfin catfishes (Pisces: Loricariidae). Zootaxa 1109: 57-68.

Copp G.H., Templeton M., Gozlan R.E. 2007. Propagule pressure and the invasion risks of non-native freshwater fishes: a case study in England. Journal of Fish Biology 71 (Suppl. D): 148-159.

DOI: $10.1111 / \mathrm{j} .1095-8649.2007 .01680 . x$

Copp G.H., Vilizzi L., Mumford J., Fenwick G.V., Godard M.J. 2009. Calibration of FISK, an invasiveness screening tool for non-native freshwater fishes. Risk Analysis 29 (3): 457-467.

DOI: 10.1111/j.1539-6924.2008.01159.x

Copp G.H., Vilizzi L., Gozlan R.E. 2010. The demography of introduction pathways, propagule pressure and occurrences of non-native freshwater fish in England. Aquatic Conservation: Marine and Freshwater Ecosystems 20 (5): 595-601.

DOI: $10.1002 /$ aqc. 1129
Duggan I.C., Rixon C.A.M., MacIsaac H.J. 2006. Popularity and propagule pressure: determinants of introduction and establishment of aquarium fish. Biological Invasions 8 (2): 377-382.

DOI: $10.1007 / \mathrm{s} 10530-004-2310-2$

Emiroğlu Ö. 2011. Alien fish species in upper Sakarya River and their distribution. African Journal of Biotechnology 10 (73): 16674-16681. DOI: $10.5897 / A J B 10.2502$

Fuller P.L. 2003. Freshwater aquatic vertebrate introductions in the United States: Patterns and pathways. Pp. 123-152. In: Ruiz G.M., Carlton J.T. (eds.) Invasive species: Vectors and management strategies. Island Press, Washington, DC, USA.

Gozlan R.E. 2008. Introduction of non-native freshwater fish: Is it all bad? Fish and Fisheries 9 (1): 106-115. DOI: $10.1111 / \mathrm{j} .1467-2979.2007 .00267 . x$

Hill J.E., Soward J. 2015. Successful eradication of the non-native loricariid catfish Pterygoplichthys disjunctivus from the Rainbow River, Florida. Management of Biological Invasions 6 (3): 311-317. DOI: 10.3391/mbi.2015.6.3.11

Hoover J.J., Killgore K.J., Cofrancesco A.F. 2004. Suckermouth Catfishes: Threats to Aquatic Ecosystems of the United States? ANSRP Bulletin 4 (1): 1-8.

Hubilla M., Kis F., Primavera J. 2007. Janitor fish Pterygoplichthys disjunctivus in the Agusan Marsh: A threat to freshwater biodiversity. Journal of Environmental Science Management 10 (1): 10-23.

Liang S.H., Wu H.P., Shieh B.S. 2005. Size structure, reproductive phenology, and sex ratio of an exotic armored catfish (Liposarcus multiradiatus) in the Kaoping River of southern Taiwan. Zoological Studies 44 (2): 252-259.

Maceda-Veiga A., Escribano-Alacid J., De Sostoa A., Garcia-Berthou E. 2013. The aquarium trade as a potential source of fish introductions in southwestern Europe. Biological Invasions 15 (12): 2707-2716.

DOI: $10.1007 / \mathrm{s} 10530-013-0485-0$

Mendoza R., Luna S., Aguilera C. 2015. Risk assessment of the ornamental fish trade in Mexico: Analysis of freshwater species and effectiveness of the FISK (Fish Invasiveness Screening Kit). Biological Invasions 17 (12): 3491-3502.

DOI: $10.1007 / \mathrm{s} 10530-015-0973-5$

Nico L.G., Butt P.L., Johnston G.R., Jelks H.L., Kail M., Walsh S.J. 2012. Discovery of South American suckermouth armored catfishes (Loricariidae, Pterygoplichthys spp.) in the Santa Fe River drainage, Suwannee River basin, USA. BioInvasions Records 1 (3): 179-200. DOI: $10.3391 /$ bir.2012.1.3.04

Padilla D.K., Williams S.L. 2004. Beyond ballast water: Aquarium and ornamental trades as sources of invasive species in aquatic ecosystems. Frontiers in Ecology and the Environment 2 (3): 131-138.

Perdikaris C., Koutsikos N., Vardakas L., Kommatas D., Simonović P., Paschos I., Detsis V., Vilizzi L., Copp G. 2016. Risk screening of non-native, translocated and 
traded aquarium freshwater fish in Greece using Fish Invasiveness Screening Kit. Fisheries Management and Ecology 23 (1): 32-43.

DOI: $10.1111 /$ fme. 12149

Rixon C., Duggan I.C., Bergeron N.M.N., Ricciardi A., Macisaac H.J. 2005. Invasion risks posed by the aquarium trade and live fish markets on the Laurentian Great Lakes. Biodiversity and Conservation 14 (6): 1365-1381.

DOI: $10.1007 / \mathrm{s} 10531-004-9663-9$

Simonović P., Tošić A., Vassilev M., Apostolou A., Mrdak D., Ristovska M., Kostov V., Nikolić V., Škraba D., Vilizzi L., Copp G.H. 2013. Risk identification of non-native freshwater fishes in four countries of the Balkans Region using FISK. Mediterranean Marine Science 14 (2): 369-376. DOI: $10.12681 / \mathrm{mms} .337$

Smith N.J.H. 1981. Man, fishes, and the Amazon. Columbia University Press, New York, NY, USA.

Strecker A.L., Campbell P.M., Olden J.D. 2011. The aquarium trade as an invasion pathway in the Pacific Northwest. Fisheries 36 (2): 74-85.

Tarkan A.S., Ekmekçi F.G., Vilizzi L., Copp G.H. 2014. Risk screening of non-native freshwater fishes at the frontier between Asia and Europe: First application in Turkey of the Fish Invasiveness Screening Kit (FISK). Journal of Applied Ichthyology 30 (2): 392-398. DOI: $10.1111 /$ jai.12389.
Tarkan A.S., Marr S.M., Ekmekçi F.G. 2015. Non-native and translocated freshwater fish species in Turkey. FiSHMED Fishes in Mediterranean Environments 2015.003.

Weber C. 1991. Nouveaux taxa dans Pterygoplichthys sensu lato (Pisces, Siluriformes, Loricariidae). Revue Suisse de Zoologie 98 (3): 637-643.

Weber C. 1992. Révision du genre Pterygoplichthys sensu lato (Pisces, Siluriformes, Loricariidae. Revue Francaise d'Aquariologie Herpétologie 19 (1-2): $1-36$.

Wu L.W., Liu C.C., Lin S.M. 2011. Identification of exotic sailfin catfish species (Pterygoplichthys, Loricariidae) in Taiwan based on morphology and mtDNA sequences. Zoological Studies 50 (2): 235 246.

Yalçın Özdilek Ş. 2007. Possible threat for Middle East inland water: an exotic and invasive species, Pterygoplichthys disjunctivus (Weber, 1991) in Asi River, Turkey (Pisces: Loricariidae). Ege University Journal of Fisheries and Aquatic Sciences 24 (3-4): 303-306.

Zworykin D.D., Budaev S.V. 2013. Non-indigenous armoured catfish in Vietnam: invasion and systematic. Ichthyological Research 60 (4): 327-333.

DOI: $10.1007 / \mathrm{s} 10228-013-0356-9$

Received: 17 July 2016

Accepted: 16 September 2016

Published electronically: 31 December 2016 